Creative Commons User License: CC BY-NC-ND

Journal of Agricultural Extension

Abstracted by: EBSCOhost, Electronic Journals Service (EJS), Vol. 23 (3) July, 2019

Google Scholar, Journal Seek, Scientific Commons,

ISSN(e): 24086851; ISSN(Print); 1119944X

Food and Agricultural Organization (FAO), CABI and Scopus

http://journal.aesonnigeria.org

http://www.ajol.info/index.php/jae

http://eoi.citefactor.org/10.11226/v23i3

Email: editorinchief@aesonnigeria.org

\title{
Adaptation Strategies to Climate Change among Cereal Crop Farmers in Kita, Kayes Region of Mali
}

https://dx.doi.org/10.4314/jae.v23i3.9

\section{Dembele, Youssouf Mahamadou}

Monitoring and Evaluation Unit,

Association pour la Promotion et Protection de la Famille (APPF)

Bamako, Mali, nibanajah1@gmail.com, +22376262106

\section{Akinbile, Lukman Abiodun}

Department of Agricultural Extension and Rural Development,

University of Ibadan, Nigeria, lakinbile@yahoo.com, +2348023250454

\section{Aminu, Oluwafunmilayo Olarewaju}

Department of Agricultural Extension and Rural Development, University of Ibadan, Nigeria, funmiaminu83@gmail.com, +2348060990906

\section{Abstract}

The study examined adaptation strategies to climate change among crop farmers in Kita, Kayes region of Mali. A multistage sampling procedure was used to select 109 respondents for the study. Structured interview schedule was used to elicit responses from respondents. Data were analysed using mean, percentages and the Pearson Product Moment Correlation (PPMC). Respondents were mostly male (58.7\%), married (93.6\%) and had no formal education (87.2\%). Average age, household size, farming experience and output were $45.28 \pm 14.78$ years, $16.70 \pm 10.65$ persons. $29.70 \pm 13.75$ years and 2,335.77 $\pm 2,139.41$ tonnes, respectively. Respondents' primarily engage in crop farming (100.0\%) with the majority producing at the subsistence level (99.1\%), using sole cropping pattern (94.5\%). Information sources on climate change effects were NGOs (90.8\%) and friends/relatives (39.4\%). Knowledge of climate change effects was high (76.4\%) and prominent adaptation strategies used were timely planting $(\bar{x}=1.93)$ and planting of short cycled seed $(\bar{x}=1.12)$. Establishing cereal banks (98.4\%), building and maintenance of small dams (95.9\%), diversifying agricultural production (72.4\%) and strengthening early warning systems $(70.7 \%)$ were never used by most respondents. None of the respondents ever employed the use of zaï - planting pits, half-moon (demi-lune) and stone cord as an adaptation strategies owing to inadequate financial capability. Significant relationship existed between farm size $(r=0.201, p \leq 0.05)$, household size $(r=0.310, p \leq 0.01)$, sources of information $(r=0.447, p \leq 0.01)$, knowledge $(r=0.326, p \leq 0.01)$ and adaptation strategies. The study recommends that efforts be made by government and NGOs to disseminate and monitor farmers' use of sustainable adaptation strategies so that substantial increase in production can be attained.

Keywords: Adaptation strategies, climate change, cereal farmers, Mali 
Creative Commons User License: CC BY-NC-ND

Abstracted by: EBSCOhost, Electronic Journals Service (EJS),

Google Scholar, Journal Seek, Scientific Commons,

Food and Agricultural Organization (FAO), CABI and Scopus
Journal of Agricultural Extension

Vol. 23 (3) July, 2019

ISSN(e): 24086851; ISSN(Print); 1119944X

http://journal.aesonnigeria.org

http://www.ajol.info/index.php/jae

Email: editorinchief@aesonnigeria.org

\section{Introduction}

Climate change has been and will continue to be the principal cause of fluctuation in global food production in the arid and semi-arid tropical countries of the developing world. Intergovernmental Panel on Climate Change - IPCC (2014) reported that climate is continually changing regardless of human intervention for at least the next decades and beyond. Variability in climate had been reported to be a present and growing threat to food security and nutrition in Africa and is a particularly severe threat to countries relying heavily on agriculture (UN Economic Commission for Africa, 2019). According to Williams (2015), Africa is one of the continents worst hit by climate change with an increase in severe droughts, floods and storms expected to threaten the health of populations and economies. In the same vein, Chen, Wichmann, Luckert, Winowiecki, Förch and Läderach (2018) noted that extreme climate events such as droughts and heavy rainfall are becoming more frequent over the last decades, especially in areas such as Sub-Saharan Africa.

It is noteworthy that climate change affects agriculture more than the other sectors of the economy, especially in Africa country like Mali. Mali, like all Least Developed Countries (LDCs) has been identified as one of the most vulnerable to the adverse impacts of climate change. The IPCC reported that by 2025, 250,000 children in Mali will suffer chronic malnutrition and that climate change will cause a statistically significant proportion of this (Williams, 2015). The impact of climate change is compounded by the pressure exerted by unsustainable agricultural practices on natural resources (land, water, biodiversity). Mali experiences severe recurrent shocks particularly droughts, floods, locust infestation and irregular rainfalls causing significant reduction in agricultural yields and water resources which severely affect the livelihoods of the people and national development. These affect major staple food crops such as millet, sorghum, rice and maize grown by the cereal crop farmers in Mali. It is noteworthy that cereals dominate the Malian diet and despite this heavy dependence on agriculture, Zamudio (2016) stated that only 14 percent of the country's land territory is considered arable. This was adduced to the adverse effects of climate change that render most lands unsuitable for agricultural production. From the foregoing, the need for adaptation strategies to array of climate change effects among cereal crop farmers in Mali become imperatives.

There had been a number of interventions such as USAID's Climate Change Adaptation Activity (CCAA) - a two-year intervention in the Mopti region of Mali, Mali's National Adaptation Programme of Action (NAPA) of 2007, Permanent Interstates Committee for Drought Control in the Sahel (AGHRYMET/CLISS), Action Against Hunger intervention and Association Malienne d'éveil au Développement Durable (AMEDD) geared towards addressing climate change effects and adaptation in Mali. The interventions were meant to improve the adaptive capacity of rural population to climate change including capacity building for the most vulnerable and agriculture assistance for targeted communities. 
Creative Commons User License: CC BY-NC-ND

Abstracted by: EBSCOhost, Electronic Journals Service (EJS),

Google Scholar, Journal Seek, Scientific Commons,

Food and Agricultural Organization (FAO), CABI and Scopus

http://eoi.citefactor.org/10.11226/v23i3
Journal of Agricultural Extension

Vol. 23 (3) July, 2019

ISSN(e): 24086851; ISSN(Print); 1119944X

http://journal.aesonnigeria.org

http://www.ajol.info/index.php/jae

Email: editorinchief@aesonnigeria.org

\section{Purpose of the study}

This study ascertained the level of use of adaptation strategies to climate change effects in Kita, Kayes region of Mali. The specific objectives were to:

1. determine respondents' sources of information on climate change effects;

2. examine respondents' knowledge level of the effects of climatic change on crop production;

3. ascertain the climate change adaptation strategies utilised by respondents.

\section{Methodology}

The study was carried out in Kita, Kayes region of Mali which lies within latitude $13^{\circ} 02^{\prime} 5.66^{\prime}-$ 'W and longitude $9^{\circ} 29^{\prime 22} 22^{\prime \prime} \mathrm{N}$. The mean annual temperature for the region varies between $34.9^{\circ} \mathrm{C}$ and $25.4^{\circ} \mathrm{C}$. Kayes region has an average of $632.9 \mathrm{~mm}$ of rainfall per year or 52.7 $\mathrm{mm}$ per month. Crops grown in the region include millet, sorghum, maize, rice, groundnut, beans and vegetables. The population of the study consisted of cereal crop farmers. A multistage sampling technique was used to select respondents for the study. In the first stage, Kita cercle $(10 \%)$ was randomly selected out of the 7 cercles in Kayes region. At the second stage, 2 communes (5\%) were randomly selected out of the 49 communes in Kita cercle. These communes were Guemou Couraba and Sefeto-West with 5 and 9 villages, respectively. At the third stage, $20 \%$ of the villages in Guemou Couraba and Sefeto-West were randomly selected to give 3 villages namely; Guessebine village in Guemoucouraba and Sefeto and Djougounté in Sefeto-West. There were 101, 757 and 230 cereal crop farmers in Guessebine, Sefeto and Djougounté villages, respectively. At the fourth stage, $10 \%$ of cereal crop farmers were randomly selected from each of the villages to give a total number of 109 respondents. Respondents' output was determined for year 2016 in moule and this was converted to $\mathrm{kg}$ equivalence. One moule equals $3 \mathrm{~kg}$ and average output was determined for millet, sorghum and maize. The knowledge of respondents' on climate change was measured using a 2 point scale of agree and disagree consisting of positive and negative statements.

Correct responses were scored 1, while incorrect responses were scored 0. Adaptation strategies were measured using a 3 point scale of always, sometimes and never with scores of 2, 1 and 0 assigned, respectively. Weighted mean score was determined for each adaptation strategy. Data were analysed using both descriptive and inferential statistics. Descriptive statistics used include frequency counts, percentages and mean, while inferential statistics used was Pearson's product moment correlation.

\section{Results and Discussion}

\section{Personal and Enterprise Characteristics of Respondents}

Table 1 shows that the respondents' mean age was $45.28 \pm 14.78$ years. About $40 \%$ of the respondents were above 50 years, $37.6 \%$ were within the age category of $31-50$ years, while $22.9 \%$ were less than 31 years. This result implies that both youths and adults engage in cereal crop farming. It is noteworthy that relatively, age will determine productivity. Farmers 
Creative Commons User License: CC BY-NC-ND

Abstracted by: EBSCOhost, Electronic Journals Service (EJS),

Google Scholar, Journal Seek, Scientific Commons,

Food and Agricultural Organization (FAO), CABI and Scopus
Journal of Agricultural Extension

Vol. 23 (3) July, 2019

ISSN(e): 24086851; ISSN(Print); 1119944X

http://journal.aesonnigeria.org

http://www.ajol.info/index.php/jae

Email: editorinchief@aesonnigeria.org

who are aged lack strength to perform tedious agricultural operations and use of adaptation strategies that requires vigour. The mean age obtained in this study also suggests ageing farming population in the study area. Respondents who were male were $58.7 \%$ indicating that both men and women engaged in cereal crop farming in Mali. The involvement of women in crop farming confirms the assertion of Ketta (2017) that women produce $80 \%$ of the Mali's agricultural produce and make up $65 \%$ of the agricultural labour force, but they do not receive proportional recognition or benefits from agriculture. Badmus, Oyelere, Aremu, Orija and Atigbi (2015) reported women farmers' involvement in maize production in Oyo State, Nigeria. Similarly, Zewdu, Zenebe, Abraha, Abadi and Gidey (2016) found that both men and women in Eastern Hararghe Zone, Ethiopia participated in crop production activities. The majority of the respondents were married $(93.6 \%)$ and had no formal education $(87.2 \%)$. The low level of education of farmers might not aid the use of adaptation strategies that will aid increase in production. The mean household size was $16.70 \pm 10.65$ persons with the majority (51.4\%) having 11-20 persons in their household. Findings show that respondents had large household sizes. Previous study had shown that within the farming population, household size plays an important role in determining family labour (Garner and Ana, 2014).

Respondents were primarily farmers (100.0\%) and $56.8 \%$ had been farming for more than 26 years with mean farming experience of $29.70 \pm 13.75$ years and cultivating average farm size of $3.77 \pm 3.04 \mathrm{ha}$. This result implies that an average farmer had been practicing farming over 25 years ago. Almost all the respondents indicated that they produce cereals at the subsistence level $(99.1 \%)$ and $94.5 \%$ use sole cropping pattern. Cereals grown were millet $(7.3 \%)$, sorghum $(92.7 \%)$ and maize $(65.1 \%)$ with a mean output of $104.70 \pm 46.89$, $1,582.19 \pm 1,537.21$ and $719.66 \pm 571.41$ tonnes, respectively. The result of this study aligns with Alliance for a Green Revolution in Africa - AGRA (2017) that $90 \%$ of farmers in Mali produce cereals, primarily sorghum, millet and maize at the subsistence level. Owing to large household sizes of respondents, it can be inferred that what is produced by farmers atimes is just to meet the immediate food consumption need of household members with little or nothing for the market. Hence, it will be difficult for subsistence farmers to embrace and use adaptation strategies that require finance for their implementation and continuity. 
Creative Commons User License: CC BY-NC-ND

Abstracted by: EBSCOhost, Electronic Journals Service (EJS),

Google Scholar, Journal Seek, Scientific Commons,

Food and Agricultural Organization (FAO), CABI and Scopus

http://eoi.citefactor.org/10.11226/v23i3
Journal of Agricultural Extension

Vol. 23 (3) July, 2019

ISSN(e): 24086851; ISSN(Print); 1119944X

http://journal.aesonnigeria.org

http://www.ajol.info/index.php/jae

Email: editorinchief@aesonnigeria.org

Table 1: Personal and enterprise characteristics

\begin{tabular}{|c|c|c|c|c|}
\hline Variables & Categories & Percentage $(n=109)$ & Mean & Std. Dev. \\
\hline \multirow[t]{5}{*}{ Age } & $<31$ & 22.9 & 45.28 & 14.78 \\
\hline & $31-40$ & 18.3 & & \\
\hline & $41-50$ & 19.3 & & \\
\hline & $51-60$ & 15.6 & & \\
\hline & $>60$ & 23.9 & & \\
\hline Sex & Male & 58.7 & & \\
\hline \multicolumn{5}{|l|}{ Marital status } \\
\hline & Married & 93.6 & & \\
\hline \multirow[t]{4}{*}{ Education } & $\begin{array}{l}\text { No formal } \\
\text { education }\end{array}$ & 87.2 & & \\
\hline & Arabic & 5.5 & & \\
\hline & Primary & 4.6 & & \\
\hline & Secondary & 2.8 & & \\
\hline \multirow[t]{4}{*}{ Household size } & $1-10$ & 25.7 & 16.70 & 10.65 \\
\hline & $11-20$ & 51.4 & & \\
\hline & $21-30$ & 14.7 & & \\
\hline & $>30$ & 8.3 & & \\
\hline Primary occupation & Crop farming & 100.0 & & \\
\hline \multirow[t]{4}{*}{ Farming experience } & $7-16$ & 21.1 & 29.70 & 13.75 \\
\hline & $17-26$ & 22.0 & & \\
\hline & $27-36$ & 18.3 & & \\
\hline & $>36$ & 38.5 & & \\
\hline \multirow[t]{4}{*}{ Farm size (ha) } & $1.00-3.00$ & 58.7 & 3.77 & 3.04 \\
\hline & $3.01-6.00$ & 31.2 & & \\
\hline & $6.01-9.00$ & 5.5 & & \\
\hline & $>9.00$ & 4.6 & & \\
\hline \multirow[t]{2}{*}{ Scale of production } & Subsistence & 99.1 & & \\
\hline & Commercial & 0.9 & & \\
\hline \multirow[t]{2}{*}{ Cropping pattern } & Mixed farming & 5.5 & & \\
\hline & Sole cropping & 94.5 & & \\
\hline \multicolumn{5}{|c|}{$\begin{array}{l}\text { Cereal crops grown and average quantity } \\
\text { produced (tonnes) }\end{array}$} \\
\hline & Millet* & 7.3 & 104.70 & 46.89 \\
\hline & Sorghum* & 92.7 & 1582.19 & 1537.21 \\
\hline & Maize* & 65.1 & 719.66 & 571.41 \\
\hline Total & Juction 2016 & & 2335.77 & 2139.41 \\
\hline
\end{tabular}

${ }^{*}$ Multiple response

\section{Sources of Information on Climate Change Effects}

Table 2 shows that respondents received information on climate change effects through the NGO ( $\bar{x}=0.93)$, friends/relatives $(\bar{x}=0.44)$ and radio $(\bar{x}=0.26)$. It was observed that respondents had never received information on climate change effects from sources such as pamphlets and newspaper. Also, information on climate change is received sparingly from extension agents $(\bar{x}=0.03)$. It can be inferred that there is still dearth of information on 
Creative Commons User License: CC BY-NC-ND

Abstracted by: EBSCOhost, Electronic Journals Service (EJS),

Google Scholar, Journal Seek, Scientific Commons,

Food and Agricultural Organization (FAO), CABI and Scopus

http://eoi.citefactor.org/10.11226/v23i3
Journal of Agricultural Extension

Vol. 23 (3) July, 2019

ISSN(e): 24086851; ISSN(Print); 1119944X

http://journal.aesonnigeria.org

http://www.ajol.info/index.php/jae

Email: editorinchief@aesonnigeria.org

adaptive strategies to climate change in the study area. From the result of this study, NGOs as a source of information on climate change effects is prominent among respondents. Oyekale (2014) reported that radio is a source of information which may serve to educate farmers on pending climatic problems and that the expected impact of radio on risk adaptation can be understood from its function as the primary source of information in rural areas.

Table 2: Sources of information on climate change effects

\begin{tabular}{lcc}
\hline Sources of information & Mean & Rank \\
\hline NGOs & 0.93 & $1^{\text {st }}$ \\
Friends/relatives & 0.44 & $2^{\text {nd }}$ \\
Radio & 0.26 & $3^{\text {rd }}$ \\
Farmers' association & 0.18 & $4^{\text {th }}$ \\
Television & 0.06 & $5^{\text {th }}$ \\
Extension agents & 0.03 & $6^{\text {th }}$ \\
Bill boards & 0.02 & $7^{\text {th }}$ \\
Pamphlets & - & - \\
Newspaper & - & - \\
\hline
\end{tabular}

\section{Knowledge of Climate Change Effects}

Table 3 reveals that the majority of the respondents disagreed that shortage of rainfall result in high yield of crop (98.2\%), excessive rainfall helps conservation of soil nutrients $(91.7 \%)$, reduction in crop yield is not as a result of climate change effects $(89.9 \%)$. climate change does not reduce income generated by farmers $(89.9 \%)$, high velocity of wind does not serve as carrier of vector diseases (86.2\%), increase in temperature does not affect cereal production $(84.4 \%)$. They however agreed that there has been high incidence of diseases of cereal crops during the raining season $(97.2 \%)$, variability in rainfall distribution has affected soil fertility (93.6\%) and that prolonged dry season does not encourage cereal production (97.2\%). This shows that climate change effects are well pronounced in the study area. This findings agreed with the report of Global Climate Change Alliance (2012) that climate change effects are increasingly felt in Mali, in the form of higher temperatures, reduced precipitation (when considered over the last three decades) and a moving desertification front. Similarly, Similarly, Zamudio (2016) stated that in Mali, climate change effects such as extreme climate events; droughts and high desertification rates severely affect agricultural production and associated food security. Hence, any intervention aimed at mitigating climate change effects vis a vis increasing agricultural production should be highly welcomed in the study area. 
Creative Commons User License: CC BY-NC-ND

Abstracted by: EBSCOhost, Electronic Journals Service (EJS),

Google Scholar, Journal Seek, Scientific Commons,

Food and Agricultural Organization (FAO), CABI and Scopus

http://eoi.citefactor.org/10.11226/v23i3
Journal of Agricultural Extension

Vol. 23 (3) July, 2019

ISSN(e): 24086851; ISSN(Print); 1119944X

http://journal.aesonnigeria.org

http://www.ajol.info/index.php/jae

Email: editorinchief@aesonnigeria.org

\section{Table 3: Knowledge of climate change effects}

\begin{tabular}{clc}
\hline & \multicolumn{1}{c}{ Knowledge of climate change effects } & $\begin{array}{c}\text { Percentage Agreeing } \\
\text { (n=109) }\end{array}$ \\
\hline 1 & $\begin{array}{l}\text { There has been high incidence of diseases of cereal crops during the raining } \\
\text { season }\end{array}$ & 97.2 \\
2 & High velocity of wind does not serve as carrier of vector diseases & 13.8 \\
3 & Variability in rainfall distribution has affected soil fertility & 93.6 \\
4 & I know that shortage of rainfall results in high yield of crop & 1.8 \\
5 & Prolonged dry season does not encourage cereal production & 2.8 \\
6 & Reduction in crop yield is not as a result of climate change & 89.9 \\
7 & Changes in rainfall pattern affect cereal production level & 96.3 \\
8 & Climate change does not reduce income generated by farmers & 10.1 \\
9 & Floods do affect crop production negatively & 95.4 \\
10 & Climate change affects planting date and fruiting of crops & 97.2 \\
11 & Increase in temperature does not affect cereal production & 15.6 \\
12 & Excessive rainfall helps conserve soil nutrients & 8.3 \\
13 & Spread of pest and weed on crop land reduces cereal quality & 98.2 \\
14 & Climate change does not delay germination period of seeds & 9.2 \\
15 & Flood has taken over most agricultural land as a result of climate change & 91.7
\end{tabular}

\section{Adaptation strategies to climate change}

Table 5 shows that the respondents always employed the use of timely planting of crops $(\bar{x}=1.93)$. Adaptation strategies sometimes used by most respondents were rotation of crop land $(\bar{x}=0.71)$, planting of short cycled seed $(\bar{x}=1.12)$, pest control $(\bar{x}=0.53)$ and planting of drought resistant seed $(\bar{x}=0.83)$. This indicates that respondents understand the seasonality of crops produced as they have been producing the same crop over the years. Findings from this study implies that though respondents might not have the financial capacity to use some adaptation strategies that can bring about significant increase in their production, they were still able to employed the use of some adaptation strategies within their financial power though the level of use might not be optimal.

It was observed that none of the respondents used zaï - planting pits, half-moon and stony cord in adapting to climate change. During the course of this survey, respondents complained that the aforementioned adaptation strategies were labour intensive and that they lack the financial capability to use them. Most farmers in the study area operate at subsistence level with little or no returns from the crops produced coupled with the fact that the majority of them had large household sizes as earlier reported. This agrees with Zamudio 
Creative Commons User License: CC BY-NC-ND

Abstracted by: EBSCOhost, Electronic Journals Service (EJS),

Google Scholar, Journal Seek, Scientific Commons,

Food and Agricultural Organization (FAO), CABI and Scopus
Journal of Agricultural Extension

Vol. 23 (3) July, 2019

ISSN(e): 24086851; ISSN(Print); 1119944X

http://journal.aesonnigeria.org

http://www.ajol.info/index.php/jae

Email: editorinchief@aesonnigeria.org

(2016) that the economy of Mali is based to a large extent upon agriculture, with majority of the rural population engaging in subsistence agriculture. According to AGRA (2017), 50\% of the Malian population lives below the poverty line and Mali ranked 179 out of 188 countries in the UN Human Development Index in 2015.

Table 5: Adaptation strategies to climate change

\begin{tabular}{llcc}
\hline SN & Adaptation strategies & Mean & Rank \\
\hline 1 & Timely planting & 1.93 & $1^{\text {st }}$ \\
2 & Planting of short cycled seed & 1.12 & $2^{\text {nd }}$ \\
3 & Planting of drought resistant seed & 0.83 & $3^{\text {rd }}$ \\
4 & Rotation of crop land & 0.71 & $4^{\text {th }}$ \\
5 & Use of improved seed & 0.69 & $5^{\text {th }}$ \\
6 & Pest control & 0.53 & $6^{\text {th }}$ \\
7 & Use of agro-meteorological information & 0.50 & $7^{\text {th }}$ \\
8 & Developing new cropping systems & 0.50 & $7^{\text {th }}$ \\
9 & Use of organic fertilizer & 0.45 & $9^{\text {th }}$ \\
10 & Diversifying agricultural production & 0.37 & $10^{\text {th }}$ \\
11 & Strengthening early warning systems & 0.34 & $11^{\text {th }}$ \\
12 & Building and maintenance of small dams & 0.04 & $12^{\text {th }}$ \\
13 & Use of Zaï (planting pits) & 0.00 & $13^{\text {th }}$ \\
14 & Use of Half-moon (demi-lune) & 0.00 & $13^{\text {th }}$ \\
15 & Use of stone cord & 0.00 & $13^{\text {th }}$ \\
16 & Establishing cereal banks & 0.02 & $13^{\text {th }}$ \\
\hline
\end{tabular}

\section{Relationship between Selected Independent Variables and Adaptation Strategies}

Table 6 shows that the relationship between household size of the respondents and adaptation strategies was significant $\left(r=0.310^{* *}, p \leq 0.01\right)$. This indicates that the higher the household size of respondents, the more they use adaptation strategies. It can be inferred that large household size contributes positively to increase in the use of use adaptation strategies as respondents can employ the use of family labour on their farms. There was a significant relationship between farm size $\left(r=0.201^{*}, p \leq 0.05\right)$ and adaptation strategies. This implies that respondents with large farm size tend to use more adaptation strategies relative to those with small farm size. A significant relationship existed between sources of information $\left(r=0.447^{* *}, p \leq 0.01\right)$ and adaptation strategies implying that increase in information on climate change effects will stimulate increase in the use of adaptation strategies. Also, there was an inverse significant relationship between knowledge $(r=-$ $\left.0.326^{* *}, p \leq 0.01\right)$ and adaptation strategies. This implies that high knowledge level might not necessarily translate to increase in the use of adaptation strategies. This might be traceable to the fact that use of adaptation strategies can be constrained by factors beyond farmers' control; such as financial incapability or labour availability. However, the relationship between 
Creative Commons User License: CC BY-NC-ND

Abstracted by: EBSCOhost, Electronic Journals Service (EJS),

Google Scholar, Journal Seek, Scientific Commons,

Food and Agricultural Organization (FAO), CABI and Scopus
Journal of Agricultural Extension

Vol. 23 (3) July, 2019

ISSN(e): 24086851; ISSN(Print); 1119944X

http://journal.aesonnigeria.org

http://www.ajol.info/index.php/jae

Email: editorinchief@aesonnigeria.org

age, years of farming experience and adaptation strategies was not significant. This implies that the aforementioned variables do not significantly determine the adaptation strategies used by respondents. The inverse relationship between age $(r=-0.130, p>0.05)$ and adaptation strategies suggest that farmers who are younger employ the use of adaptation strategies more than the older folks.

\begin{tabular}{ll}
$\begin{array}{l}\text { Table 6: } \\
\text { strategies }\end{array}$ & Relationship between selected independent variables and adaptation \\
\hline Variables & r-value \\
\hline Age & -0.130 \\
Farming experience & 0.013 \\
Household size & $0.310^{* *}$ \\
Farm size & $0.201^{*}$ \\
Source of & $0.447^{* *}$ \\
information & $-0.326^{* *}$ \\
\hline
\end{tabular}

${ }^{\star \star} \mathrm{P} \leq 0.01 ;{ }^{*} \mathrm{P} \leq 0.05$

\section{Conclusion and Recommendations}

The knowledge of climate change effects was high, but optimal use of adaptation strategies was not recorded among respondents. Hence, respondents had low adaptive capacity. Household size, farm size, source of information and knowledge significantly influence adaptation strategies. Efforts should be made by government and NGOs to disseminate and monitor farmers' use of sustainable adaptation strategies so that substantial increase in production can be attained. There should be a mechanism such that access to credit facility will be made possible to crop farmers by the institute of finance on behalf of ministry of agriculture to allow farmers' use of adaptation strategies.

\section{References}

Alliance for a Green Revolution in Africa - AGRA (2017). AGRA Mali Operational Plan. Retrieved from $h$ ttps://agra.org/wp-content/uploads/2017/12/agra-mali-final.pdf

Badmus, A. I., Oyelere, G. O., Aremu, A. O., Orija, S. J. and Atigbi, T. O. (2015). Women farmers' contributions to maize production in Afijio Local Government of Oyo State International Journal of Applied Agricultural and Apicultural Research Vol (1\&2): 77-85

Chen M., Wichmann B., Luckert M., Winowiecki L, Förch W and Läderach P (2018). Diversification and intensification of agricultural adaptation from global to local scales. Retrieved from https://doi.org/10.1371/journal.pone.0196392

Garner E. and Ana Paula de la O Campos (2014). Identifying the 'family farm': An informal discussion of the concepts and definitions. ESA Working Paper No. 14-10. Agricultural Development Economics Division, Food and Agriculture Organization of the United Nations, Rome. Retrieved from $h t t p: / / w w w . f a o . o r g / 3 / a-i 4306 e . p d f$ 
Creative Commons User License: CC BY-NC-ND

Abstracted by: EBSCOhost, Electronic Journals Service (EJS),

Google Scholar, Journal Seek, Scientific Commons,

Food and Agricultural Organization (FAO), CABI and Scopus

http://eoi.citefactor.org/10.11226/v23i3
Journal of Agricultural Extension

Vol. 23 (3) July, 2019

ISSN(e): 24086851; ISSN(Print); 1119944X

http://journal.aesonnigeria.org

http://www.ajol.info/index.php/jae

Email: editorinchief@aesonnigeria.org

Global Climate Change Alliance - GCCA (2012). Global Climate Change Alliance in Mali. http://www.climatefundsupdate.org/listing/global-climate-change-allianc

Intergovernmental Panel on Climate Change - IPCC (2014). Climate Change 2014. Synthesis Report Summary Chapter for Policymakers IPCC, p. 31. Retrieved from https://www.ipcc.ch/site/assets/uploads/2018/02/AR5_SYR_FINAL_SPM.pdf

Ketta O. (2017). Mali's government has pledged to empower women in agriculture. Retrieved from $h$ ttps://www.one.org/us/blog/agriculture-women-land-rights-mali/

Oyekale A. S. (2014). Impacts of climate change on livestock husbandry and adaptation options in the Arid Sahel Belt of West Africa: Evidence from a baseline survey. Asian Journal of Animal and Veterinary Advances, Vol 9: 13-26. https://scialert.net/abstract/?doi=ajava.2014.13.26

Zamudio, A. N. (2016). Review of current and planned adaptation action in Mali. CARIAA Working Paper no. 11. International Development Research Centre, Ottawa, Canada and UK Aid, London, United Kingdom. Available online at: www.idrc.ca/cariaa

Zewdu A., Zenebe G., Abraha B., Abadi T. and Gidey N. (2016). Assessment of the gender role in agricultural activities at Damota Kebele of Haramaya District, Eastern Hararghe Zone, Ethiopia. Journal of Culture, Society and Development Vol 26: $20-26$ https://www.researchgate.net/publication/315686194_Assessment_of the_Gender_R ole_in_Agricultural_Activities_at_Damota_Kebele_of_Haramaya_District_Eastern_Har arghe_Zone_Ethiopia 